\title{
Stroke terminology in Mexico: Consensus using the Delphi method
}

\author{
Juan M. Marquez-Romero ${ }^{1 *}$, Jessica Romo-Martínez², Juan M. Calleja-Castillo ${ }^{3}$ Carlos Espinoza-Casillas ${ }^{4}$, \\ Carlos A. Prado-Aguilar ${ }^{5}$, and Valery Feigin ${ }^{6}$ \\ ${ }^{1}$ Department of Neurology, Hospital General de Zona 2, Instituto Mexicano del Seguro Social, Aguascalientes, Mexico; ${ }^{2}$ Private Practice, Torre Médica \\ CMQ, Aguascalientes, Mexico; ${ }^{3}$ Department of Neurology, Instituto Nacional de Neurología y Neurocirugía "MVS," Mexico City, Mexico; ${ }^{4}$ Department \\ of Neurology, Centro Médico ISSEMYM, Metepec, Mexico; ${ }^{5}$ Coordinación Medica Auxiliar de Investigación en Salud, Instituto Mexicano del Seguro \\ Social, Aguascalientes, Mexico; ${ }^{6}$ National Institute for Stroke and Applied Neurosciences, Faculty of Health and Environmental Studies, Auckland \\ University of Technology, Auckland, New Zealand
}

\begin{abstract}
Background: In the Spanish language, there exists a considerable heterogeneity regarding the translation and use of the term "stroke," which has multiple implications for epidemiology and science as well as the general population. Objective: The objective of the present study was to complete a Delphi exercise on the terminology for the Spanish equivalent for the term "stroke" in a group of Mexican experts in vascular neurology. Methods: A 3-phase consensus process was carried out using the Delphi method. The convened experts who agreed to participate completed an initial questionnaire. Subsequent questionnaires were designed based on the initial results. The final consensus was validated in a different group of researchers. Results: 69 stroke specialists participated in the first round, $78 \%$ also participated in the second round, and $72 \%$ in all three rounds. From an initial list of 33 terms derived from an initial search of the medical literature in Spanish, a consensus of more than $70 \%$ was obtained to designate stroke as: "Enfermedad Vascular Cerebral (EVC)" and ischemic and hemorrhagic stroke as "infarto cerebral" and "hemorragia cerebral,"respectively. Likewise, the so-called "stroke units" were designated as "unidades neurovasculares". Conclusions: This is the first work that seeks to solve, through a consensus methodology, the great diversity that exists in the Spanish language regarding the terminology of stroke.
\end{abstract}

Key words: Stroke. Delphi method. Terminology. Mexico. Brain stroke. Brain haemorrhage.

\section{Terminología para enfermedad vascular cerebral en México: consenso utilizando el método Delphi}

\section{Resumen}

Antecedentes: Existe gran heterogeneidad en cuanto a la traducción y el uso del término stroke en el idioma español, lo cual tiene múltiples implicaciones epidemiológicas, científicas y demográficas. Objetivo: El objetivo de este estudio fue llevar a cabo un ejercicio Delphi acerca de la nomenclatura para el término stroke en un grupo de expertos en neurología vascular en México. Métodos: Se realizó un proceso de consenso en tres fases mediante el método Delphi. Los expertos

Correspondence:

Juan M. Marquez-Romero

E-mail: scint1st@gmail.com
Date of reception: $22-02-2020$

Date of acceptance: 12-05-2020

DOI: 10.24875/RMN.20000015
Available online: $21-10-2020$

Rev Mex Neuroci. 2020;21(5):187-191

www.revmexneurociencia.com

1665-5044/ @ 2020 Academia Mexicana de Neurología A.C. Published by Permanyer. This is an open access article under the CC BY-NC-ND license (http://creativecommons.org/licenses/by-nc-nd/4.0/). 
convocados completaron un cuestionario inicial; los cuestionarios subsecuentes se basaron en los resultados iniciales. El consenso final se validó en otro grupo de investigadores. Resultado: 69 especialistas participaron en la primera ronda y $72 \%$ en las tres rondas. De una lista inicial de 33 términos, se obtuvo el consenso de más de 70\% para referirse a stroke como enfermedad vascular cerebral. Conclusiones: Este es el primer trabajo que busca resolver la diversidad existente en la terminología para denominar al trastorno que en inglés se conoce como stroke.

Palabras clave: Enfermedad vascular cerebral. Método Delphi. México. Ictus. Infarto cerebral. Hemorragia cerebral.

\section{Introduction}

Unlike other Spanish-speaking countries such as Spain, where the term "ictus" is widely used", in Mexico, there is no unified terminology to refer to stroke. This has resulted in the indiscriminate use of multiple words, both among health professionals and the general population. Such a diversity of terms can sometimes convey misconceptions about the nature of vascular pathology in the central nervous system. The lack of clarity in terminology is one of the potential causes of the low level of knowledge about vascular risk factors and warning symptoms in the general population ${ }^{2}$, which, in turn, decreases the possibility of early detection and treatment.

Due to the health implications of the variability in the terminology used to refer to the pathology that affects the brain vessels, we designed the present study with the primary objective of obtaining a standardized terminology for application in the medical, academic, and general population settings.

\section{Methods}

We carried out a 3-phase consensus process using the Delphi method.

\section{Phase 1}

a) Search of the scientific literature in Spanish.

Search strategy and selection criteria.

References for this work were identified by searching the IBECS, Lilacs and Scielo electronic databases. No date limits were used, and we included articles published until July 2018. Types of articles included reviews, original studies, and treatment guidelines. The search was conducted exclusively in Spanish using the terms: first term: "México," "mexicano," and "mexicana;" second term: "epidemiologia," "mortalidad," "carga," "incidencia," "prevalencia," "pronostico," "registro," "vigilancia," "factores de riesgo," "prevención," and "diagnóstico;" and third term: "accidente cerebrovascular," "ataque cerebral," "enfermedad cerebrovascular," "enfermedad vascular cerebral," "EVC," "ACV," "AVC," "evento vascular cerebral," "isquémico," "hemorrágico," "infarto cerebral," "hemorragia cerebral," "trombosis cerebral," "hemorragia intracerebral," "ictus," "vascular," "neurológica," "terapia intensiva," "unidad de cuidados," "unidad de ictus," and "especializado." Based on the title and summary, articles for full-text review were selected.

b) Creation of an initial list of terms

The terms found in the text of the articles identified in the literature search were used to create a list. The first list was for the translation of stroke as an umbrella term for cerebrovascular disease and another three lists were created to designate the subtypes of ischemic and hemorrhagic stroke and for the designation for stroke units.

\section{Phase 2}

A 3-round Delphi process ${ }^{3}$ was carried out. Neurology experts specialized in stroke who agreed to participate in the three rounds of questionnaires were involved. Questionnaires were designed to achieve a consensus of opinions about which words should be used to designate stroke and its subtypes. Participants were recruited from among those attending the Annual Meeting of the Mexican Association of Stroke. The questionnaires were applied electronically through an online platform. The surveys could be quickly answered, with an average completion time of fewer than $10 \mathrm{~min}$. All participants remained anonymous during the process; their responses were tracked through initials and the date of birth. After each round, their answers were used as feedback to update the following questionnaire, eliminating the less popular terms.

\section{Phase 3}

Once consensus was reached with the findings of the first two phases, a small group of experts was asked for their views on the resulting terms, thus concluding the consensus process. The final list of selected words was sent to all participants by e-mail. 
Table 1. Terms included in the first questionnaire

\begin{tabular}{|c|c|}
\hline Terms for stroke & Translation to English (literal) \\
\hline Enfermedad Vascular Cerebral & Vascular cerebral disease \\
\hline Ictus & Ictus \\
\hline Evento Vascular Cerebral & Cerebral vascular event \\
\hline Enfermedad Cerebrovascular & Cerebrovascular disease \\
\hline Evento Cerebrovascular & Cerebrovascular event \\
\hline Accidente Vascular Cerebral & Cerebral vascular accident \\
\hline Accidente Cerebrovascular & Cerebrovascular accident \\
\hline Derrame & Spillover \\
\hline Embolia & Embolism \\
\hline Apoplejía & Apoplexy \\
\hline Stroke & Stroke (in English) \\
\hline $\begin{array}{l}\text { Terms for ischemic stroke } \\
\text { Accidente Cerebrovascular Isquémico } \\
\text { EVC Isquémico } \\
\text { Infarto Cerebral } \\
\text { Ictus Isquémico } \\
\text { Evento Cerebrovascular Isquémico } \\
\text { Ataque cerebral Isquémico } \\
\text { Embolia } \\
\text { Ischemic Stroke }\end{array}$ & $\begin{array}{l}\text { Ischemic cerebrovascular accident } \\
\text { Ischemic cerebral vascular event } \\
\text { Cerebral infarct } \\
\text { Ischemic ictus } \\
\text { Ischemic cerebrovascular event } \\
\text { Ischemic cerebral attack } \\
\text { Embolism } \\
\text { Ischemic stroke (in English) }\end{array}$ \\
\hline $\begin{array}{l}\text { Terms for hemorrhagic stroke } \\
\text { Accidente Cerebrovascular Hemorrágico } \\
\text { EVC Hemorrágico } \\
\text { Hemorragia Cerebral } \\
\text { Hemorragia Intracerebral Espontánea } \\
\text { Ictus Hemorrágico } \\
\text { Evento Cerebrovascular Hemorrágico } \\
\text { Derrame } \\
\text { "Hemorrhagic Stroke" }\end{array}$ & $\begin{array}{l}\text { Hemorrhagic cerebrovascular accident } \\
\text { Hemorrhagic cerebral vascular event } \\
\text { Cerebral hemorrhage } \\
\text { Spontaneous intracerebral hemorrhage } \\
\text { Hemorrhagic ictus } \\
\text { Hemorrhagic cerebrovascular event } \\
\text { Spillover } \\
\text { Hemorrhagic stroke (in English) }\end{array}$ \\
\hline $\begin{array}{l}\text { Terms for stroke unit } \\
\text { Unidad Neurovascular } \\
\text { Unidad de Ictus } \\
\text { Centro de Atención de Infarto Cerebral } \\
\text { Unidad de Ataque Cerebral } \\
\text { Unidad de Stroke } \\
\text { "Stroke Unit" }\end{array}$ & $\begin{array}{l}\text { Neurovascular unit } \\
\text { Ictus unit } \\
\text { Cerebral infarct care center } \\
\text { Cerebral attack unit } \\
\text { Unit of stroke } \\
\text { Stroke unit (in English) }\end{array}$ \\
\hline
\end{tabular}

\section{Results}

Table 1 shows the initial list derived from the literature search. This list includes 33 items that were used in the first questionnaire. Seventy-one specialists participated in the first round of the Delphi process. However, the responses of two specialists had to be eliminated because the country where they practiced neurology was not Mexico (1 in Costa Rica and 1 in El Salvador). Of the remaining 69 specialists, $77.5 \%$ (55 specialists) answered the second questionnaire and 51 participated in the third $(72 \%)$. Consensus was achieved when at least $70 \%$ of the respondents considered the term as the most appropriate.

For the final phase of the consensus, three prominent specialists with extensive experience in epidemiology and research methodology were invited to test the pilot process of the final term list. They all agreed to participate. The consensus reached in this phase was 100\%; the final list formed by the terms is shown in table 2.

The four terms obtained are recommended as translation standards and for use in scientific manuscripts, scientific dissemination texts, advertising campaigns, 
Table 2. Final terms

\begin{tabular}{|l|l|l|}
\hline In English & In Spanish & $\begin{array}{l}\text { Acronym in } \\
\text { Spanish }\end{array}$ \\
\hline Stroke & Enfermedad Vascular Cerebral & EVC \\
\hline $\begin{array}{l}\text { Ischemic } \\
\text { stroke }\end{array}$ & Infarto Cerebral & IC \\
\hline $\begin{array}{l}\text { Hemorrhagic } \\
\text { stroke }\end{array}$ & Hemorragia Cerebral & HC \\
\hline $\begin{array}{l}\text { Stroke unit } \\
\text { Unidad Neurovascular }\end{array}$ & UNV \\
\hline
\end{tabular}

informational brochures, and any other written or electronic media that deal with the topic of stroke.

\section{Discussion}

This is the first project that seeks to solve the great diversity that exists in Mexico regarding the terminology referring to stroke through a consensus methodology. The literature search carried out in the first phase of the study demonstrated the wide variety of terms currently in use. This variety of terms can have severe and multiple implications, both medical and otherwise. Below we discuss some of the most important.

In epidemiology, it may cause underreporting in morbidity/mortality statistics reported in the country due to inadequate coding. For example, in a study of 26 death certificates completed in a general hospital in Mexico ${ }^{4}$, it was found that only $26.9 \%$ of them had good quality data, and in $30.7 \%$ of them, the quality was rated as poor to terrible. The most common error was the presence of blank spaces followed by the use of abbreviations. Although the above data do not refer exclusively to stroke, data obtained from death certificates show that in Mexico's general hospitals stroke constitutes between 20 and $50 \%$ of the causes of hospitalization ${ }^{5}$, so a substantial amount of those certificates does contain data from patients with stroke.

Another example related to this problem is the inclusion of the diagnosis of "embolia" in both the "Guide for the filling of death certificates and fetal death"6, from the General Directorate of Health Information of Mexico, and the "Self-learning guide for the correct filling of the death certificate" , from the Mexican Center for the Classification of Diseases. The term "embolia" although widely used among the general population of Mexico, it is also sometimes encountered in the medical literature. For example, in a study of patients with cardioembolic ischemic stroke (IS), the only term used throughout the text to refer to (IS) is "embolia"8. Given the fact that "embolia" means obstruction caused by an embolus; the use of this term excludes both hemorrhagic stroke and IS due to other mechanisms such as atherosclerosis and hypoperfusion. Therefore, its use is highly discouraged.

Another example at the international level is the World Health Organization's web site, where the corresponding page in Spanish of the page dedicated to providing general information about stroke defines it as cerebrovascular accident ${ }^{9}$.

We believe that the use of the term accident implies inevitability or randomness in its origin. Since most of the risk of stroke derives from chronic or potentially preventable factors, the use of the term: cerebrovascular accident has been discouraged and broadly eliminated in English ${ }^{10}$. Nonetheless, to this day, the Code $8 \mathrm{~B} 2 \mathrm{O}^{11}$, of the international classification of diseases in its current revision in Spanish, corresponds to cerebrovascular accident.

Another aspect where the standardized use of words has implications beyond the clarity of language is that of clinical research since the use of different terms makes it difficult to search for medical literature. Lack of standardization may introduce biases when conducting systematic reviews, meta-analyses, or even in simple searches derived from daily clinical practice. For example, in a single study of morbidity and mortality in cardiac and cerebral vascular diseases ${ }^{12}$, five different terms and abbreviations are used interchangeably throughout the manuscript: "enfermedad cerebrovascular, ECV, AVC, enfermedad isquémica cerebrovascular y evento cerebrovascular" (cerebrovascular disease, ECV, AVC, ischemic cerebrovascular disease, and cerebrovascular event), ultimately making unclear whether the epidemiological data reported corresponded to stroke or to IS.

The health needs of Mexico and Latin America require high-quality data. Therefore, we believe that a systematic approach is essential to be able to adequately estimate the burden of disease associated with stroke, to increase comparability among populations, and to design campaigns of awareness for the general population, among other essential objectives. These goals are hampered by the lack of homogeneity in the terminology of stroke. We acknowledge that the issue of heterogeneity was earlier addressed by the Iberoamerican Society of Cerebrovascular Disease (SIECV) that resulted in the recommendation for the use of the term "ictus." Unfortunately, as previous research shows, the knowledge and use of the term "ictus" are very scarce among the general population in Mexico'. 
Consistently, our results also show that a highly selected sample of neurologists did not consider the use of the term "ictus" to be the most adequate, in fact, "ictus" did not even reach the last round of the Delphi exercise, which illustrates the difficulty of homologizing the terminology according to the recommendations of the SIECV. Further complicating the problem, it is worth noting that despite its recommendation, the SIECV does not use in its name the term "ictus" but instead cerebrovascular disease.

Hence, we consider that the development of standardized terms to designate stroke is a first step toward improving the quality of epidemiological data and informative materials. Even though we agree that the use of ictus as the standard translation of stroke is preferable, our results show that among Mexican professionals in vascular neurology, "ictus" has yet to be widely accepted, thus severely difficulty its widespread use among the general population.

As with any result derived from a consensus approach, the present study has the limitation that its results could only reflect the opinions of its participants. However, the Delphi method has been widely used in medicine to solve problems analogous to the one presented in this paper ${ }^{13,14}$. In addition, we consider that we have reached a large percentage of consensus in a highly qualified population of Mexican vascular neurology practitioners. Likewise, the experts who participated in the final validation also showed a broad consensus on the usefulness and relevance of the results. It follows that this work may be useful for health professionals, educators, and the general population.

\section{Conclusions}

Projects aimed at measuring the potential impact of the use of these results and their applicability in other Spanish-speaking countries should be further researched.

\section{Acknowledgments}

The authors would like to thank the Delphi process respondents for their voluntary participation in this project.

To Brigitte van Gils for the editorial review of the manuscript.

\section{Conflicts of interest}

None.

\section{Funding}

This research received no specific grant from any funding agency in the public, commercial or not-forprofit sectors.

\section{Ethical disclosures}

Protection of human and animal subjects. The authors declare that the procedures followed were in accordance with the regulation of the relevant clinical research ethics committee and with those of the code of ethics of the World Medical Association (Declaration of Helsinki).

Confidentiality of data. The authors declare that they have followed the protocols of their work center on the publication of patient data.

Right to privacy and informed consent. The authors have obtained the written informed consent of the patient or subjects mentioned in the article, the corresponding author is in possession of this document

\section{References}

1. Herrera-García JC, Arias-Sánchez E, Martínez L, González S, López-Martínez C, Pérez-Sosa J, et al. ICTUS: nuevo término universal en una muestra poblacional. Med Surg. 2013;20:146-50.

2. Gongora-Rivera F, Gutierrez-Jimenez E, Zenteno MA, Investigators G. Knowledge of ischemic stroke among a Mexico city population. J Stroke Cerebrovasc Dis. 2009;18:208-13.

3. McMillan SS, King M, Tully MP. How to use the nominal group and Delphi techniques. Int J Clin Pharm. 2016;38:655-62.

4. Hernandez-Mier C. Calidad del llenado del certificado de defunción y muerte fetal en un hospital de segundo nivel en México. Gac Int Cienc Forense. 2014;11:18-24.

5. Hoy-Gutiérrez MJ, González-Figueroa E, Kuri-Morales P. Epidemiología de la enfermedad cerebrovascular. Dirección general de epidemiología, secretaría de Salud. Gac Méd Méx. 1996;132:223-30.

6. Dirección General de Información en Salud. Guía Para el llenado de los Certificados de Defunción Y Muerte Fetal. $3^{\text {rd }}$ ed. Mexico: Dirección General de Información en Salud; 2007.

7. Centro Mexicano Para la Clasificación de Enfermedades. Guía de Autoaprendizaje Para el llenado Correcto del Certificado de Defunción. Mexico: Centro Mexicano para la Clasificación de Enfermedades; 2004.

8. García-Villarreal OA, Heredia-Delgado JA. Orejuela izquierda en la enfermedad reumática mitral: principal fuente embolígena en la fibrilación auricular. Arch Cardiol Méx. 2017;87:286-91.

9. Accidente Cerebrovascular. Available from: https://www.who.int/topics/ cerebrovascular_accident/es. [Last accessed on $2017 \mathrm{Jul} 15]$.

10. Storey CE, Pols H. A history of cerebrovascular disease. In: Finger F, Boller F, Tyler KL, editors. Handbook of Clinical Neurology. Netherlands: North-Holland Publishing Company; 2010.

11. World Health Organization. International Statistical Classification of Diseases and Related Health Problems. Available from: https://www.icd. who.int/browse11/l-m/en2018.

12. Monroy ÓV, Aldatz FS, Guerra AF, Verdejo J, Bello MÁ, Violante R, et al. Morbilidad y mortalidad de la enfermedad isquémica del corazón y cerebrovascular en México. 2005. Arch Cardiol Méx. 2007:77:31-39.

13. Bishop DV. Why is it so hard to reach agreement on terminology? The case of developmental language disorder (DLD). Int J Lang Commun Disord. 2017;52:671-80.

14. Weir A, Holmich P, Schache AG, Delahunt E, de Vos RJ. Terminology and definitions on groin pain in athletes: building agreement using a short Delphi method. Br J Sports Med. 2015;49:825-7. 